\title{
Penal welfarism og norsk sikkerhetspsykiatri, 1895-1940*
}

\author{
Av Hilde Dahl, forsker II, Kompetansesenter for sikkerhets-, \\ fengsels- og rettspsykiatri Helse Midt., Norge
}

\begin{abstract}
This article presents the early decades of Norwegian forensic psychiatry as a basis for exploring David Garland's term «penal welfarism». While Garland focuses primarily upon penalties and prisons, I find it relevant to look at a type of sanction not officially defined as punishment according to Norwegian law. Insanity has provided exemption from criminal punishment in Norway since 1842. Yet criminals considered dangerous to themselves or others have been housed in criminal asylums since 1895, which is the same year Garland argues that a transformation in penal strategies occurred in Britain (Garland, 1985).
\end{abstract}

\section{Innledning}

I artikkelen presenteres de to asylene for kriminelle sinnssyke i Norge, Kriminalasylet og Reitgjerdet asyl, med den hensikt å drøfte Garlands begrep «penal welfarism». Eksempelet med etableringen av kriminalasylene gir et innblikk i den norske utviklingen av strafferettslige strategier og moderne kriminalpolitikk.

I sin bok Punishment and Welfare fra 1985 argumenterer David Garland for at de strafferettslige strategiene i Storbritannia gjennomgikk en grunnleggende omforming fra $1895 \mathrm{og}$ frem til første verdenskrig, og at ideer om kriminalitetsforebygging nå ble kombinert med elementer fra velferdsmodellen. Garland mener den nye strafferettslige strategien inneholder prinsipper som individualisering, vurdering, klassifisering og normalisering, og han omtaler denne strategien som «penal welfarism» (Garland, 1985). I en tidligere artikkel har han argumentert for at moderne straffekultur ikke var et resultat av nye velferdsideer, men at det var heller tvert om. Garland skriver at: «there is a sense in which the normalizing function of the Welfare State owes its origin and possibility to the realm of penality» (Garland, 1981, s. 30). Poenget hans er at en ny strafferettslig strategi gjorde det mulig å formulere det velferds-rasjonale som siden ble grunnleggende for vel- 
ferdsstaten, og særlig er det de normaliserende prinsippene ved strategien som også er å finne i velferdsmodellen. ${ }^{1}$

Toby Seddon har med henvisning til Garland hevdet at psykisk helse og den nye spesialiteten retts- og sikkerhetspsykiatri var en sentral del av strategien i denne perioden (Seddon, 2007). Seddons påstand stemmer for norske forhold. Norges første asyl for kriminelle sinnssyke menn, Kriminalasylet, åpnet i 1895 og introduserte en helt ny måte å reagere mot denne gruppen med lovbrytere. Perioden Garland skisserer passer altså nøyaktig med åpningsåret for det første asylet for farlige og kriminelle sinnssyke menn i Norge. 28 år etter åpnet et større asyl for kriminelle sinnssyke menn, også dette asylet lå i Trondheim. Da Reitgjerdet åpnet i 1923 var det for å møte det økte behovet for slike spesialplasser. I samtiden ble kriminalasylene også omtalt som særasyler, mens i nyere tid er begrepet sikkerhetspsykiatri blitt den offisielle benevnelsen. Artikkelen drar veksler på min forskning på norsk sikkerhetspsykiatri i perioden 1895-1940 (Dahl, 2018).

\section{Et norsk eksempel}

Norge er i dag forbundet med begrep som oljefond, likestilling og sosialdemokrati. For et drøyt århundre siden var derimot Norge et ganske annerledes samfunn. Omkring år 1900 var befolkningen omtrent halvparten så stor, landet hadde ennå ikke oppdaget sine oljeressurser, kvinner hadde ikke stemmerett - det hadde heller ikke menn uten eiendom eller inntekt - og den sosialdemokratiske samfunnsmodellen Skandinavia er kjent for var ennå ikke utviklet. ${ }^{2}$ Politisk fungerte landet med en form for liberalt laissez faire-styre, hvor hvert enkelt individ sørget for seg selv og hvor familien utgjorde det sosiale og økonomiske nettverket. I løpet av de siste to tiårene av 1800-tallet inntok myndighetene gradvis en mer aktiv rolle ved å øke sine forpliktelser overfor befolkningen. Endringer i styringen av det kriminalpolitiske feltet var et sentralt trekk ved denne perioden, særlig gjennom innføringen av en rekke nye lover og institusjoner. Dette er i overenstemmelse med det Garland kaller «modern penal complex», et straffekompleks bestående

* Title in English: Penal welfarism and Norwegian forensic psychiatry, 1895-1940

1. Norsk Ordbok (2005): rasjonale (et rasjonale - flere rasjonaler) 'tilgrunnliggende begrepsapparat; samlede prinsipper; fornuftsgrunnlag' [eng.; substantivering av lat. adv. rationale, sm. ord som rasjonal]

2. Mye kan sies om nyere utviklingstrekk i likestilling og likhet når det kommer til kjønn og økonomi, men for dette formålet holder det å male med bred pensel. 
av ulike lover og tiltak rettet mot de delene av befolkningen som begikk uønskede handlinger eller som levde på uønskede måter (Garland, 1985, s. 238).

Retts- og sikkerhetspsykiatrien etablerte seg i denne perioden som en spesialitet og profesjon i flere europeiske land, dels i sammenheng med den løpende diskursen om forbrytelse og straff, dels i kjølvannet av nye progressive lover om behandling av sinnssyke, i Norge som følge av arbeidet til legen Herman Wedel Major (Høyer, 2016). Da loven om sinnssykes behandling ble vedtatt i 1848 var Norge et av de første land i verden som fikk politisk gjennomslag for en moderne sinnssykelov (Hermundstad, 2005). Retts- og sikkerhetspsykiatrien i Norge var imidlertid også et svar på et praktisk-juridisk problem. To lovbestemmelser ble opptakten til et opplevd problem med sinnssyke kriminelle. Med inspirasjon i den franske kriminalloven fra 1810 ble det i Norge vedtatt en kriminallov i 1842 . Kriminalloven slo fast at sinnssyke kriminelle ikke kunne idømmes fengselsstraff. Denne generelle bestemmelsen bar med seg en erkjennelse av at skyld har begrensninger, en forståelse av at sinnssykdom er en lidelse, men også en anerkjennelse av at straff kan være noe annet enn en moralsk respons. Tanken var nå at straff skulle ha et sosialt formål og fungere rehabiliterende og forebyggende. England, Frankrike, Irland og Sveits hadde allerede vedtatt lignende lover om utilregnelighet (Kelly, 2009, s. 362). Den norske loven hadde en bestemmelse om at «forbryderske» sinnssyke ikke skulle behandles i alminnelige asyl. De ble vurdert som et uroelement, som virket forstyrrende på behandlingen av vanlig sinnssyke og dessuten ble de ofte ansett som uhelbredelige.

De to lovbestemmelsene medførte et problem for myndighetene som nå sto uten mulighet for å reagere mot kriminelle sinnssyke. Ikke kunne de straffes og ikke kunne de legges inn til behandling. Ofte ble slike utilregnelige lovovertredere likevel plassert i asyl, ettersom andre muligheter ikke eksisterte. Dermed protesterte asyldirektører over hele landet, de gikk lei av å måtte forholde seg til denne gruppen kriminelle, og dette ansporet en langvarig debatt. Særlig tok debatten utgangspunkt i de kriminelle sinnssyke som ble vurdert som farlige, for det at farlige menn ble satt fri eller plassert sammen med mer «verdige» behandlingstrengende var i strid med hva mange opplevde som rett og rimelig. Etter flere år med diskusjon om de farlige og kriminelle sinnssyke ble Kriminalasylet vedtatt opprettet i 1895, det samme året Garland setter som åpningsår for den nye og moderne straffestrategien han kaller «penal welfarism».

\section{Kriminalasylet}

Like ved Ila kirke, i utkanten av Trondheim by, sto det en tom fengselsbygning i årene 1888 til 1895 . Den var opprinnelig bygd i 1833 i tilknytning til militæran- 
legget på Skansen og først kjent under det dystre navnet «Slaveriet», men på 1870tallet hadde bygningen blitt brukt som kvinnefengsel, da formelt kjent som «Afdeling B af Trondhjems Strafanstalt». Bygningen var av mur, hadde gitter foran alle vinduene og var omringet av et fire meter høyt gjerde. Ikke langt unna lå Trondhjem Hospital, som hadde vært i kontinuerlig drift siden 1277, og bare to hus bortenfor lå et asyl kalt Tronka, som ble opprettet som dårekiste i 1776 og hadde fungert som pleiestiftelse for sinnssyke siden 1842. Fra Ila kirke var det enkel gangavstand inn til sentrum av Trondhjem by, som med sine den gang tretti tusen innbyggere og mange viktige næringer var en storby å regne, i alle fall etter norsk målestokk på slutten av 1800-tallet. Den tomme fengselsaktige bygningen fikk en ny funksjon da Stortinget i 1894 bestemte at «Afdeling B af Trondhjems Strafanstalt» skulle brukes som kriminalasyl, inntil en mer egnet bygning kunne bygges eller lokaliseres. Norges første landsdekkende asyl for kriminelle og farlige sinnssyke ble dermed åpnet i det gamle «slaveriet» på Skansen den 1. februar 1895.

Kriminalasylet skulle være en midlertidig ordning. Medisinaldirektør Michael Holmboe ville ikke anbefale bygget som permanent asyl fordi: «dens dystre, fængselsagtige Udseende og dens indestængte Beliggenhed midt inde i Byen med indskrænket Lufteplads og liden Adgang til Beskjæftigelse af Patienterne i det Frie gjør dette utilraadelig» (Sth.Prp.No.73, 1894). Holmboes betenkning viser den vanskelige avveiningen mellom kontroll og omsorg. Like fullt var det bred enighet om nødvendigheten av et slikt asyl, hvor: «saadanne Fanger eller andre Sindssyge som paa Grund af moralsk Degeneration eller Samfundsfarlighed ikke ansees egnede til Behandling i almindeligt Sindssygeasyl» skulle være pasienter (Norges Officielle Statistik, 1895, s. 85). For å få til en mer tilfredsstillende løsning ville det være nødvendig med en langt større og mer egnet bygning, men en slik løsning lå altså lengre frem i tid. Medisinaldirektøren mente derfor at: «der paa Grund af de tiltagende Vanskeligheder ved at faa [de kriminelle sinnssyke] anbragt, strax bør træffes Forføininger til deres Behandling» (Sth.Prp.No.73, 1894). Det ble besluttet at asylet skulle drives av en psykiater og etter medisinfaglige prinsipper, men at Justisdepartementet skulle ha ansvaret for å vedta innleggelser og utskrivelser (Thomassen, 2015, s. 42). Dette gjør Kriminalasylet til den eneste helseinstitusjonen i Norge som har vært underlagt justismyndighetene. ${ }^{3}$ Hensikten var å motvirke den såkalte asylsuvereniteten som var hjemlet $\mathrm{i}$

3. Lignende institusjoner i for eksempel Italia har alltid vært underlagt justismyndighetene, se: De Vito, Christian Giuseppe (2013): Forensic psychiatric units in Italy from the 1960s to the present. In: International Journal of Law and Psychiatry, 37 (2014) 127-134. 
sinnssykeloven av 1848, et prinsipp som la opp til at asyldirektørene avgjorde innleggelser og utskrivelser. En slik suverenitet utfordret tanken om samfunnsvern og kunne ikke gjelde for et kriminalasyl. Hensynet til samfunnsvernet fikk veie tyngst i valg av sted og retningslinjer, for de kriminelle sinnssyke var en gruppe pasienter som krevde kontroll.

De første årene hadde Kriminalasylet autorisasjon for, og plass til, bare 15 pasienter. Det var da seks voktere som gikk døgnskift (Karlsholm, 2015). I 1900 ble asylet utvidet ved at bygningens andre etasje ble tatt i bruk og kapasiteten økte til 35 pasienter. I hver etasje var det et større rom som ble brukt som arbeids-, fritids- og spiseværelse, i tillegg til mindre soverom. De første årene var det noen fengselsceller som ble brukt til isolasjon av pasienter som ble opplevd som vanskelige eller farlige. Mens psykiateren Waldemar Bødker (1824-1901) var bestyrer i årene 1895-1901 ble enkelte pasienter lenket fast i veggen for korte eller lengre perioder dersom det ble ansett som nødvendig, eller de ble isolert på cellene.

Da psykiateren Hans Evensen (1868-1953) overtok som bestyrer i 1901 fikk cellene en mer tvetydig funksjon. Evensen var ung og hadde nye ideer med seg fra kontinentet, han var også en markant motstander av tvangsbruk. Hvert år sendte han inn den påkrevde tvangsprotokollen til Justisdepartementet med påskriften: «her brukes ikke tvang». Flere av pasientene så dessuten på cellene som et privilegium og ikke som straff. De gamle fengselscellene fikk dermed fungere både som privat rom og beskyttelse mot aggressivitet, der pasientene selv kunne dekorere og innrede etter eget ønske. Asylets ansatte hadde høy toleranse for trusler og truende adferd og enerommene inngikk som belønning i det som fremstår som en daglig forhandling mellom pasientene og personalet. Sosionom og historiker Åse Riaunet har beskrevet praksisen som at: «sindighet så ut til å være asylets strategi, og hele forløpet ser ut til å ha vært en eneste lang forhandling» (Riaunet, 2014, s. 49). Evensen fikk stor innvirkning på hvordan asylet opererte, og praksisen med pasientmedvirkning ser ut til å ha vart lenge etter hans avgang. Evensen ble direktør for Gaustad asyl i 1915 og den etter hvert så kjente psykiateren Johan Scharffenberg (1869-1965) vikarierte i stillingen som direktør en kort periode frem til legen Johan Sofus Widerøe (1864-1930) tok over i $1916 .{ }^{4}$ Både

4. For mer om psykiater Johan Scharffenberg, se; Nissen, Hartvig (1939): Psykiaternes innflytelse på strafferett og fangebehandling. I: Frihet - Sannhet. Festskrift til Johan Scharffenberg, Oslo, eller; Søbye, Espen (2010): En mann fra forgangne århundrer, Overlege Johan Scharffenbergs liv og virke 1869-1965. Oslo: Forlaget Oktober. 
Scharffenberg og Widerøe ser ut til å ha videreført den praksisen Evensen etablerte.

\section{Reitgjerdet}

Reitgjerdet asyl åpnet i 1923 og var det andre asylet for farlige og vanskelige sinnssyke som ble vedtatt i Norge. Allerede ved opprettelsen av Kriminalasylet ble det forutsett et behov for flere slike spesialplasser. I regjeringens innstilling fra 1894 om bevilgning til opprettelse av kriminalasyl ble det bemerket at det antallet «kriminalpatienter» kommisjonen gikk ut fra måtte være et beskjedent estimat og at det var: «Grund til at tro, at Antallet senere er tiltaget, desuden er der neppe tvivlsomt, at der i Strafanstalterne hensidder flere sindssyge eller psychisk defekte Fanger, hvis Overførelse til en Sindssygeanstalt vilde være ønskelig» (Sth.Prp.No.73, 1894). Det ble altså allerede på 1890-tallet initiert en debatt om hvordan og hvor en større institusjon med det samme formålet som Kriminalasylet kunne opprettes.

At også Reitgjerdet ble lagt til Trondheim hadde samme forklaring som Kriminalasylet; det var en ledig bygning der som kunne passe til formålet. Reitgjerdet ble opprinnelig åpnet den 27. august i 1861 som en pleiestiftelse for spedalske og var det siste i rekken av fire slike leprahospitaler i Norge (Breida, 2011). Da den norske legen Gerhard Henrik Armauer Hansen oppdaget leprabasillen sent på 1870-tallet, åpnet dette for bedre forebygging og behandling av spedalskhet (Godøy, 2015). På få tiår var det derfor nesten ingen spedalske pasienter igjen på Reitgjerdet pleiestiftelse. I 1914 ble det vedtatt å legge ned leprahospitalet og bygningen kunne dermed omreguleres til annen drift. Under planleggingen av Reitgjerdet ble det lagt til grunn en svakere vektlegging av kriminalitet som kriterium for innleggelse, men dette var snarere en utvidelse av målgruppen enn en forandring av formålet.

Reitgjerdet lå landlig til, med dyrket mark på begge sider av bygningen og utsikt over Trondheimsfjorden. Dette skulle være fordelaktig for pasientenes tilfriskning og rehabilitering, med mye frisk luft og anledning til aktiviteter utendørs, i motsetning til det fengselsaktige og innestengte Kriminalasylet. Den fordelaktige plasseringen gjorde det mulig å se for seg sikkerhetsforanstaltninger som lett kunne tilpasses bygningsmassen. Det var ikke nødvendig med mange høye gjerder siden det åpne landskapet gjorde rømning vanskelig. I tillegg bød området på muligheter for fysisk arbeid som kunne tilbys de nye pasientene. Dette var derfor en bygning som, i motsetning til Kriminalasylet, i langt større grad tilfredsstilte også de medisinske kravene til et behandlingssted; det var luftig og landlig, med rom for utendørs aktivitet og rom for felles aktiviteter innendørs. I 1919 ble 
det av Stortinget vedtatt å omdanne Reitgjerdet til sinnssykeasyl for særlig vanskelige og farlige pasienter og Stortinget bevilget samtidig penger til ombygging og forbedring av sikkerheten (Blom m.fl., 1980, s. 14).

Ved åpningen i 1923 tok psykiateren Karl Anton Andresen (1869-1938) over som direktør for både Kriminalasylet og Reitgjerdet asyl, og selv om han fikk ansvar for en langt større pasientpopulasjon markerte hans direktørvirke ikke et brudd med den praksisen Evensen hadde etablert. I tråd med samtidens ideer om arbeidsterapi i behandlingen av sinnssyke, ble det opprettet salmaker-verksted, skredderstue, vevstue, skomakerverksted og et lite trykkeri, i tillegg til arbeidet som kunne utføres utendørs tilknyttet gårdsdriften eller steinhuggeriet. At de to asylene fikk felles direktør understreket de to asylenes felles formål. Direktør Andresen var spesialist i psykiatri og hadde lang erfaring med institusjonsledelse. I 1939, kort tid etter Andresens død, tok legen Egil Rian (1904-1982) over som direktør. Han var medlem av det norske nasjonalistpartiet Nasjonal Samling (NS) fra 1934. Under den tyske okkupasjonen samarbeidet NS med okkupantene, som det eneste norske partiet naziregimet ikke forbød, og partiet arbeidet aktivt for å nazifisere det norske samfunnet. Rian kom til å spille en sentral rolle i utformingen av okkupasjonsregimets tvangssterilisasjons-politikk under krigsårene, men uten at dette gav særlige utslag på behandlingen av pasientene ved kriminalasylene. Han var godt likt av pasienter og ansatte, og steriliserings- og kastreringstallene ved Reitgjerdet asyl var relativt lave i forhold til hva lovgivningen i denne perioden åpnet for (Myhre og Thomassen, 2014). Nasjonal Samling sørget for en innskjerping av lovgivningen på et rasehygienisk grunnlag, men praksisen fikk aldri det omfanget regimet hadde håpet på (Haave, 2016). Den restriktive holdningen til tvang, som Evensen hadde ført med seg inn i praksisen i 1900, fortsatte dessuten gjennom Rians ledertid.

Den 21. mars 1923 kom den aller første pasienten til Reitgjerdet asyl, som da var autorisert for 105 pasienter. Den offisielle åpningen var ikke før 4.april 1923, men hele 13 pasienter ble innlagt før denne datoen og røper hvor tiltrengt spesialplassene i dette asylet var opplevd å være. Autorisasjonen ble raskt utvidet og 135 pasienter ble innlagt på Reitgjerdet det aller første året. Under okkupasjonsårene steg antallet pasienter til 280, noe som utgjorde en betydelig belastning på bygningsmassen og personalet. Asylet sorterte administrativt under Socialdepartementet, som var det departementet som avgjorde inn- og utskrivelser. På samme måte som med Kriminalasylet, ble dermed Reitgjerdet asyl også unndratt den suvereniteten som alminnelige asyl hadde når det kom til innleggelser og utskrivelser. Samfunnsvernet var stadig det primære formålet og kontrollen med pasientene var imperativ. 
Allerede fra Reitgjerdet åpnet i 1923 ble det gradvis etablert en form for samarbeid mellom de to institusjonene. De som forsøkte å rømme fra Reitgjerdet ble overført til Kriminalasylet, som hadde bedre sikkerhetsforanstaltninger. Tilsvarende kunne pasienter som viste god oppførsel overføres til Reitgjerdet, hvor tilværelsen var friere og aktivitetene mer variert. De best fungerende pasientene på Reitgjerdet fikk dessuten bo på Brøset gård, som lå ved den nordre innkjøringen til asylet. ${ }^{5}$ Hvile, beskyttelse, god ernæring, arbeid og aktiviteter ble viktige elementer i behandlingen og det ble fremhevet i regulativet ved asylene at pasientene skulle møtes med respekt og verdighet. ${ }^{6}$

Behandlingen som ble praktisert i førkrigsårene ved Kriminalasylet og Reitgjerdet var trolig inspirert av det som er bedre kjent under det engelske navnet «moral treatment». Psykologen Gunvald Hermundstad har definert den moralske behandlingen som «opplæring i skikk og bruk. Det dreide seg om trening i dagliglivets ferdigheter som personlig hygiene, konversasjon, bordmanerer, høflighet [...]» (Hermundstad, 2005, s. 42). Medisinprofessor Georg Høyer har definert denne behandlingstradisjonen som en tredje retning som: «bygde på en slags miljøterapeutisk tilnærming med sterk vekt på en human behandling av pasientene, der tvang ikke hadde noen plass» (Høyer, 2016). Høyer hevder at den moralske behandlingen fikk liten innflytelse i norsk psykiatri, mens Hermundstad påpeker at den norske psykiatri-reformatoren Herman Major var en ivrig tilhenger av moralsk behandling og at han som en følge av det kan beskrives som: «Norges første miljøterapeut» (Hermundstad, 2005, s. 42). Uavhengig av merkelapp var formålet med behandlingen på asylene å både helbrede og rehabilitere. Dette skulle skje gjennom bruk av tre elementer vi kjenner fra den moralske behandlingen: klassifisering av sykdommen, arbeid og aktivitet, samt at pasientene ble adskilt fra det øvrige samfunnet. Vesentlig i denne sammenhengen er at disse elementene var

5. Gården brant ned til grunnen da en pasient satte fyr på bygningen i 1931: http://www.strinda historielag.no/wiki/index.php?title=Mordbrenneren_fra_Br\%C3\%B8set

6. Til eksempel står det i Regulativ for Reitgjerdet asyl, $\S 11$ at: «Til eller om de syke er ingen annen betegnelse enn «syk» eller «patient» tillatt. Personalet må altid vise en høflig og rolig optreden og fremforalt unngå å såre eller hidse de syke ved overlegen eller bydende tiltale. Enhver strid med de syke skal unngåes, hvert rimelig ønske så vidt mulig imøtekommes. Ingen er berettiget til å tvinge de syke, men har i tilfelle å henvende sig til nærmeste overordnede. Legemlig mishandling vil medføre øieblikkelig fjernelse fra tjenesten og avsked overensstemmende med bestemmelsene i lov av 15. Februar. 1918 om offentlige tjenestemenn og i tilfelle anmeldelse til påtalemyndigheten.» (Approbert ved kgl. resolusjon av 16. Februar 1923) 
lett forenlige med de prinsippene Garland fører opp som sentrale for den strafferettslige strategien i denne perioden; individualisering, vurdering, klassifisering og normalisering.

\section{Omsorg og kontroll, ikke straff}

I mange tiår var Kriminalasylet og Reitgjerdet asyl de eneste institusjonelle mulighetene for reaksjoner mot sinnssyke kriminelle i Norge. Totalt 1811 pasienter ble innlagt her i perioden 1895-1987, hvorav 687 av dem i årene før 1940 (Dahl, 2017). Et mindretall av disse var erklært farlige for den offentlige sikkerhet, de øvrige var enten kriminelle eller bare vanskelige å håndtere i ordinære asyl. Asyldirektør Hans Evensen skrev om to pasienter i Kriminalasylets årsberetning for 1901 at: «Det kan synes at være en unødig hård forholdsregel at internere $\mathrm{i}$ et kriminalasyl sindssyge som disse to, som i kortere eller længere tider, hvori de er forholdsvis fri for sygdom, og hvis farlighed vesentlig består deri, at de forgriber sig på andres eiendom eller kommer i konflikt med politiet. Men på det trin, hvorpå sindsygepleien i vort land står, synes der for tiden ikke at være annen måde at drage omsorg for dem på» (Norges Officielle Statistik, 1910, s. 110). Etter det Evensen beskriver var det slik at mangelen på andre alternativer gjorde Kriminalasylet til en nødvendig ordning for de farlige sinnssyke, uavhengig av hva den opplevde farligheten ble begrunnet $i$, ettersom ingen andre institusjoner kunne tilby bedre omsorg og samtidig utøve kontroll med pasientene.

Som historien om opprettelsen av særasylene for kriminelle sinnssyke viser, var disse institusjonene og denne reaksjonsformen tett knyttet til justismyndighetene, selv om innleggelse her ikke var å regne som straff. Samfunnsvernet var det primære formålet med særasylene og dette knyttet dem til den straffestrategien som ble utviklet i Norge i denne perioden. Etableringen sammenfalt med en gryende interesse for kriminalvitenskap blant leger og jurister, noe som også førte til stiftelsen av Den Norske Kriminalistforening i 1892. Slik ble diskusjonene om farlige sinnssyke flettet sammen med andre kriminalistiske debatter (Dahl, 2018, kap. 5). Hensikten med asylene var å beskytte samfunnet fra farlige og kriminelle sinnssyke, og bidra til bedre kriminalitetskontroll. Som institusjoner tilsvarer asylene det Garland omtaler som en av de mange nye sanksjonene som ble tilgjengelig for retten omkring århundreskiftet 1900: «detention in an institution for the mentally defective» (Garland, 1985, s. 6). Dette plasserer kriminalasylene godt innenfor Garlands begrep «penal welfarism» og hans teoretiske avgrensning. Historien om de norske særasylene for kriminelle sinnssyke kan altså illustrere de utviklingstrekkene Garland tegner opp i sin teori, og slik belyse utviklingen av strafferettslige strategier i Norge. 


\section{Ny norsk straffestrategi?}

Det moderne straffe-komplekset Garland viser til i «penal welfarism» er forklart som: «the framework of penal sanctions, institutions and representations assembled in the UK by 1914» (Garland, 1985, s. 18). Dette betyr sanksjoner, institusjoner og andre uttrykk for norsk strafferett i samme periode, dersom begrepet skal anvendes i en norsk kontekst. Det er både likheter og forskjeller å finne. Norge undergikk en lang periode med politiske og juridiske reformer i siste halvdel av 1800-tallet, slik som Storbritannia. Det er flere eksempler på lover som åpnet for nye sanksjoner og reaksjoner fra denne norske reformperioden. Først var straffeprosessloven av 1887, som medførte en radikal forandring av tidligere straffeprosess både med hensyn til domstolsordningen og saksbehandlingen. Vergerådsloven av 1896 hadde en kriminalpolitisk karakter og innledet en epoke hvor statlig kontroll med barn og unges adferd fikk utgjøre et viktig element i samfunnsvernet (Stang Dahl, 1978). Løsgjengerloven av 1900 gav reaksjonsmuligheter mot tiggere, løsgjengere og alkoholikere. ${ }^{7}$ Til sist kan nevnes straffeloven av 1902, som var en av de første i Europa til å gjennomføre ideene til den sosiologiske strafferettsskolen (Mæland, 2000, s. 330). Disse lovene muliggjorde også en rekke nye institusjoner i Norge, som til eksempel skolehjem og arbeidsanstalter. Slik var utviklingen også i Storbritannia, og Garland gjør et poeng av at de britiske lovene: «shared a common feature of specialization and classification» (Garland, 1985, s. 22). Et interessante trekk i norsk sammenheng er at ikke alt som inngikk i det nye straffe-komplekset var å regne som straff, og slik sett må også lovene som autoriserte de to kriminalasylene inngå.

I debattene på 1890-tallet ble forslaget om å internere kriminelle sinnssyke $\mathrm{i}$ egne asyler definert som noe annet enn straff. Riksadvokat Bernhard Getz omtalte de ulike reaksjonene som var tiltenkt kriminelle sinnssyke, løsgjengere og alkoholikere som noe: «konstrueret som Straf, [men] dog i sit Væsen mere en Sikkerhetsforanstaltning» (DNKF, 1894, s. 4). Selv om denne typen sanksjoner ikke juridisk sett ble definert som straff, var altså planleggingen av dem en del av debatten om straff og kriminalitetsforebygging. Særasylene for de kriminelle sinnssyke ble opprettet for å beskytte samfunnet mot farlige individer, men ikke for å straffe dem. For noen betød slike asylopphold et bedre og mer stabilt liv, ettersom mange av pasientene ved disse asylene kom fra det nedre sjiktet i samfunnet og levde ressursfattige liv. Institusjonen tilbød sosialitet, aktivitet, husrom og variert

7. Tiggere og løsgjengere viser til personer uten fast beskjeftigelse og ofte uten fast bopel. På svensk: lösdrivare, tattare, vagrantar. På dansk: landstryger, vagabond, omstreifende. 
kost (Dahl, 2017). Det er nok likevel slik at denne typen sanksjoner kunne oppleves som straff og at det for mange var vanskelig å skille slike asylopphold fra fengselsopphold. Dette er også i overenstemmelse med hvordan Garland omtaler institusjonene for de mentalt avvikende som en funksjonell del av det «moderne straffekomplekset» i Storbritannia (Garland, 1985, s. 6).

For Garland er det en relasjon mellom det han kaller «the disciplinary logic of control» og «social welfare rationale». Garland gir ikke klare definisjoner selv, men utmeisler derimot denne kontroll-logikken som det korrigerende elementet i de sosiale teknologiene. Strategien var nå rettet mot individet, i motsetning til den klassiske strafferetten som fokuserte på samfunnets gjengjeldelse. Garland forstår de ulike sosiale tiltakene rettet mot de fattige i befolkningen som velferdstiltak og han setter dem i sammenheng med prinsippene i strafferetten. I sin nyeste bok The Welfare State: A very short introduction (2016) presenterer Garland tre definisjoner av velferdsstaten. Først, en definisjon av velferdsstat som baserer seg på tiltak som sørger for statlige overføringer til de fattige. Den andre definisjonen ser velferdsstaten som en besørger av trygdeordninger, sosiale rettigheter og offentlige tjenester. En tredje definisjon omhandler måter å administrere og styre på som innebærer at staten tar en aktiv rolle overfor befolkningens liv (Garland, 2016, s. 7-8). Disse tre definisjonene representerer ulike sirkler i Garlands forståelse av velferdsmodellen som angir kvantitative forskjeller i et bredt omriss av velferdsstaten.

Historiker Anne Lise Seip har betegnet Norge som en sosialhjelpsstat i perioden 1880-1920, og den påfølgende perioden 1920-1975 som «velferdsstaten» (Seip, 1994). En annen historiker, Knut Kjeldstadli, har definert velferdsstatsperioden som årene 1935-1980 (Kjeldstadli, 1998). Seip og Kjeldstadli skisserer velferdsstaten som prinsipielt ulik sosialhjelpsstaten, særlig på grunn av den tilsiktede omfordelende effekten velferdsmodellen har på samfunnet. De peker dermed mot en kvalitativ forskjell. Velferdsstaten sørget for en rekke tjenester til alle innbyggerne gjennom universelle rettigheter, slik som helsetjenester, utdanning, sykelønn, pensjon og mere. Den tidlige sosialhjelpen var rettet mot enkeltgrupper og enkeltindivider gjennom mindre tiltak eller moderate utbetalinger, og som system understreket dette det individuelle ansvaret. For Seip og Kjeldstadli er det avgjørende at velferdsmodellen ble definert ut fra å være sosiale rettigheter som skulle gjelde alle, og ikke bare være en bistand til noen få. Garland gjør altså ikke denne distinksjonen. Dersom vi legger Seip og Kjeldstadli sin distinksjon til grunn i drøftingen av den norske utviklingen, gir det mindre mening å samle velferd og straffestrategi i ett begrep. Den norske sosial- og kriminalpolitiske utvik- 
lingen ligner imidlertid den i Storbritannia, og slik sett vil Garlands brede omriss av velferdsmodellen også kunne anvendes på norske forhold.

Det er kontinuerlig stridigheter omkring hvordan vi skal straffe og hvem som skal straffes. Ulike visjoner om hvordan kriminalitet bør sanksjoneres eller kan forebygges skaper en evig diskurs om straff. Garland er klar over dette når han markerer året 1895 som et år for endring, men poenget hans er at av og til skjer det mer markante forandringer som indikerer slutten og begynnelsen på ideologiske paradigmer. Hans begrep «penal welfarism» betegner et nytt paradigme på straff, eller kanskje helst straffestrategi. I 1895 ble «the Gladstone Committee Report» utgitt og denne rapporten reflekterte et skifte i holdninger overfor strafffanger. Her sto det skrevet at: «We start from the principle that prison treatment should have as its primary and concurrent objects, deterrence and reformation». ${ }^{8}$ Garland fremsetter dette som startskuddet for en ny strategisk holdning på det strafferettslige og kriminalpolitiske feltet.

Det er vanskelig å sette et like bestemt startskudd for den norske utviklingen. At Kriminalasylet ble opprettet dette året kan ikke stå som eksempel på en strategisk holdningsendring på det strafferettslige og kriminalpolitiske feltet. Da gir det mer mening å si at relevante endringer i Norge kan sirkles inn ved hjelp av tre begivenheter og tre årstall. Innføringen av straffeprosessloven av 1887, stiftelsen av Den Norske Kriminalistforening i 1892 og den nye straffeloven av 1902. ${ }^{9}$

Straffeprosessloven av 1887 introduserte juryordningen og markerer starten på det omfattende reformarbeidet som strafferetten nå ble gjenstand for. Allerede i denne loven blir problemet med kriminelle sinnssyke adressert for gjennom sakkyndigeordningen og adgangen til å begjære rettspsykiatriske vurderinger ble det mulig å klassifisere de sinnssyke som farlige for den offentlige sikkerhet (Dahl, 2018). Dette åpnet dessuten for bruk av mer enn bare juridisk kunnskap i en straffeprosess. Denne sammenføyningen av ulike kunnskapsfelt fikk en annen viktig arena utenfor rettsalen da Den Norske Kriminalistforening ble stiftet i 1892, som den første i Norden. ${ }^{10}$ Her dannet det seg et interessefellesskap hvor jurister, leger, psykiatere og fengselsfolk bidro til kriminalpolitisk nytenkning på en måte

8. Prisons over Two Centuries. http://www.justicestudies.com/pubs/prisonhistory.pdf [lesedato:16.09.18]

9. Se for eksempel: Flaatten, Sverre og Heivoll, Geir (red) (2014): Straff, lov, historie. Historiske perspektiver på Straffeloven av 1902, Akademisk Publisering, Oslo 2014.

10. Danmark fikk en Kriminalistforening i 1899, Sverige i 1911, Finland i 1934 og Island i 1949. 
som ble bestemmende for arbeidet med ny strafferett (Dahl, 2018). Den nye straffeloven av 1902 rundet på mange måter av dette reformarbeidet, men loven ble samtidig hyllet som begynnelsen på en moderne æra i strafferett i Europa og USA (Mueller, 1961). 1902-loven tok opp i seg en rekke former for rett og redefinerte dermed strafferetten. Begivenheter som de over nevnte førte norsk strafferett og kriminalpolitikk en retning som stemmer med det Garland beskriver som «penal welfarism», først og fremst ved at strafferetten fikk et større kunnskaps- og handlingsrepertoar.

\section{Litteraturliste}

Blom, Knut m.fl. (1980): (Blomkommisjonen) Rapport om forholdene ved Reitgjerdet sykehus, fra den granskningskommisjon som ble nedsatt ved kongelig resolusjon 29.februar 1980

Breida, Jan P. (2011): Reitgjerdet Pleiestiftelse for spedalske - et 150-årsminne. En hjørnestein i norsk helsevesen. Årbok for Strinda historielag, Trondheim.

Dahl, Hilde (2018): Institusjonaliseringen av farlighet, sinnssykdom og samfunnsvern i Norge. En studie av farlige kriminelle sinnssyke pasienter i Kriminalasylet og Reitgjerdet asyl, 1895-1940. Avhandling NTNU 2018:274.

Dahl, Hilde (2017): 'Insane criminals' and the 'criminally insane': criminal asylums in Norway, 1895-1940. In: Journal of History of Psychiatry 28(2):0957154X1769100

DNKF: (Den Norske Kriminalistforening): Forhandlinger ved den Norske Kriminalistforenings møte (1894:4): Stensiltrykk. General Books LLC, USA.

Garland, David (2016): the Welfare State: A very short introduction. UK: Oxford University Press

Garland, David (1985): Punishment and welfare. A history of penal strategies. UK: Gower Aldershot.

Garland, D. (1981): The Birth of the Welfare Sanction. UK: British Journal of Law and Society, Vol.8, Number 1.

Godøy, Bjørn (2015): Ti tusen skygger. En historie om Norge og de spedalske. Oslo: Spartacus Forlag.

Hermundstad, Gunvald (2005): Herman Wedel Major og byggingen av Gaustad asyl. Del 1: Kallet. Tidsskrift for Norsk psykologforening, Vol 42, nummer 1, 2005, side 3-8.

Høyer, Georg (2016): Herman Wedel Major - personen, legen og reformatoren. I: Tidsskrift for den Norske Legeforening, 2016;136: 1106-8

Haave, Per (2016): Sterilisering under hakekorset. I: Norgeshistorie.no https://www.norges historie.no/andre-verdenskrig/artikler/1743-sterilisering-under-hakekorset.html [lesedato: 23.12.18]

Karlsholm, Mads (2015): Overgangen fra vokter til pleier i sinnssykeomsorgen. Masteroppgave, Institutt for historie og klassiske fag, NTNU.

Kelly, Brendan D. (2009): Criminal insanity in 19th-century Ireland, Europe and the United States: Cases, contexts and controversies. In: International Journal of law and Psychiatry. 32(2009) pp: 362-368 
Kjeldstadli, Knut (1998): Aschehougs norgeshistorie. Bind. 10: Et splittet samfunn, 1905-1935. Oslo: Aschehoug Forlag.

Mueller, Gerhard O.W. (1961): Foreword. I: The American Series of Foreign Penal Codes. Rothham \& Co. South Hackensack, New Jersey.

Myhre, Eivind og Øyvind Thomassen (2014): The Construction of an Accepted Masulinity: Castration in High Security Psychiatric Institutions in Norway 1923-1945. I: Lander, Ravn og Jon (2014) Masculinities in the Criminological Field. London: Routledge.

Mæland, Henry John (2000): Fra Kriminalloven til Straffeloven. I: Tidsskrift for Strafferett, 2002-4, s. 326-337.

Norges Officielle Statistik (1901): Årsberetning for Kriminalasylet 1901. I: Oversigt over Sindssygeasylernes Virksomhed, Aaret 1901. NOS, IV, 058, SSB.

Norges Officielle Statistik (1895): Oversigt over Sindssygeasylernes Virksomhed, Aaret 1895. NOS, III, 274, SSB.

Riaunet, Åse (2014): Oppdrag, pasienter og praksiser. Kriminalasylet i Trondheim, 1895-1905. Masteroppgave, Institutt for tverrfaglige kulturstudier, NTNU.

Seddon, T. (2007): Punishment and madness. Governing prisoners with mental health problems. UK: Routledge.

Seip, Anne Lise (1994): Veiene til velferdsstaten: norsk sosialpolitikk 1920-1975. Oslo: Gyldendal Norsk Forlag.

Stang Dahl, Tove (1978): Barnevern og samfunnsvern: om stat, vitenskap og profesjoner under barnevernets oppkomst i Norge. Pax, 1978.

Sth.Prp. No. 73 (1894): Om Bevilgning til Anlæg og Drift af et midlertidig Kriminalasyl.

Thomassen, Øyvind (2015): Asylene for de sinnssyke og farlige mennene - Kriminalasylet og Reitgjerdet. Norsk Rettsmuseums skriftserie, Trondheim. 